MT-DP - 2008/3

\title{
Measuring Factor Income Shares at the Sectoral Level
}

ÁKOS VALENTINYI - BERTHOLD HERRENDORF 
Discussion papers

MT-DP $-2008 / 3$

Institute of Economics, Hungarian Academy of Sciences

KTI/IE Discussion Papers are circulated to promote discussion and provoque comments. Any references to discussion papers should clearly state that the paper is preliminary. Materials published in this series may subject to further publication.

Measuring Factor Income Shares at the Sectoral Level

\author{
Ákos Valentinyi \\ University of Southampton \\ Institute of Economics, Hugarian Academy of Sciences; \\ CEPR. \\ E-mail: avalentinyi@mnb.hu \\ Berthold Herrendorf \\ Department of Economics \\ W.P.Carey School of Business \\ E-mail: berthold.herrendorf@asu.edu
}

2008 March

ISBN 978-963-9796-10-2

ISSN $1785-377 \mathrm{X}$ 


\title{
Measuring Factor Income Shares at the Sectoral Level ${ }^{*}$
}

\author{
Ákos Valentinyi ${ }^{\dagger}$ \\ Berthold Herrendorf ${ }^{\ddagger}$ \\ February 2008
}

\begin{abstract}
Many applications in economics use multi-sector versions of the growth model. In this paper, we measure the income shares of capital and labor at the sectoral level for the U.S. economy. We also decompose the capital shares into the income shares of land, structures, and equipment. We find that the capital shares differ across sectors. For example, the capital share of agriculture is more than two times that of construction and more than 50\% larger than that of the aggregate economy. Moreover, agriculture has by far the largest land share, which mostly explains why it has the largest capital share. Our numbers can directly be used to calibrate standard multi-sector models. Alternatively, if one wants to abstract from differences in sector capital shares, our numbers can be used to establish that this is not crucial for the results.

Keywords: input-output tables; industry-by-commodity total requirement matrix; sector factor shares
\end{abstract}

JEL classification: $\mathrm{O} 41 ; \mathrm{O} 47$

*We thank the editor Tim Kehoe and two anonymous referees for suggestions that improved the paper considerably. We thank Edward Prescott for many helpful discussions about input-output tables, Randal Konoshita from the BLS for providing us with additional data, and Ben Bridgman, Cara McDaniel, Paul Schreck, and the audiences at ASU and the Federal Reserve Bank of Minneapolis for comments.

${ }^{\dagger}$ University of Southampton, Highfield, Southampton SO17 1BJ, UK; Institute of Economics of the Hungarian Academy of Sciences; CEPR. Email: valentinyia@mnb.hu

*Department of Economics, W.P. Carey School of Business, Arizona State University, Tempe, AZ 85287-3806, USA. Email: Berthold.Herrendorf@asu.edu 


\title{
A termelési tényezók jövedelemrészesedésének szektor szintü mérése
}

\author{
Ákos Valentinyi \\ Berthold Herrendorf
}

\begin{abstract}
Összefoglaló
Számos közgazdasági munka a neoklasszikus növekedési modell több szektoros változatát használja. Ebben a tanulmányban a tőke és a munka szektor szintú jövedelemrészesedését mérjük az Egyesült Államokra. A tốke jövedelem részesedét felbontjuk föld, épületek és gépek részesedésére. Munkánk során azt találtuk, hogy a tôke részesedése jelentősen különbözik szektorok között. Például, a tőke részesedése a mezőgazdaságban több mint kétszer akkora, mint az építőiparban és 50\%-kal magasabb, mint a gazdaság egészében. Számaink közvetlenül felhasználhatóak a több szektoros modellek paramétereinek kalibrálására. Ha pedig valaki el akar vonatkozatni a tőke jövedelemrészesedésének szektorok közötti különbségétől, akkor számaink felhasználhatók annak megállapítására, hogy ez lényeges-e vagy sem.
\end{abstract}

Tárgyszavak: input-output táblák; teljes ráfordítás mátrix; tényező részesedés JEL: O41; O47 


\section{Contents}

1 Introduction 1

2 The Mapping Between Multi-Sector Models and the Data 3

3 Income Shares of Capital in Industry Value Added in the Data 7

4 Income Shares of Capital at the Sectoral Level 10

5 Income Shares of Land, Structures, and Equipment in the Model Sectors 14

6 Extensions 20

6.1 Robustness ........................... 20

6.2 Factor income shares of exports and imports and the Leontief paradox . . . . . 22

6.3 Distribution costs as part of sector output . . . . . . . . . . . . 23

6.4 Multi-sector models with intermediate inputs . . . . . . . . . . . . . 24

7 Conclusion $\quad 25$ 


\section{Introduction}

Many questions in economics require the disaggregation into at least two sectors. For example, trade theorists distinguish between tradables and nontradables, growth theorists between consumption and investment, and development economists between agriculture and nonagriculture. This raises the question what production functions one should use at the sectoral level. Our purpose in this paper is to measure the factor income shares at the sectoral level for the U.S. economy.

We consider the model sectors agriculture, manufactured consumption, services, equipment, and construction. ${ }^{1}$ The advantage of considering these five sector is that we can aggregate them to the different multi-sector models typically employed in the literature: tradables versus nontradables (tradables comprise agriculture, manufactured consumption, and equipment and nontradables comprise services and construction); consumption and investment (consumption comprises agriculture, manufactured consumption, and services and investment comprises equipment and construction); agriculture and nonagriculture (nonagriculture comprises manufactured consumption, services, equipment and construction); agriculture, services, and manufacturing (manufacturing comprises manufactured consumption, construction, and equipment).

Constructing the model sectors from the data is more challenging than it may seem at first sight. The reason is that sectors in multi-sector models typically use only capital and labor to produce final output. In contrast, industries in the data use intermediate inputs, capital, and labor to produce intermediate inputs for other industries and final output. Moreover, industries in the data may produce more than one commodity and different industries may produce the same commodity. Establishing a mapping between industries in the data and sectors in the model therefore requires additional information about final output, value added, intermediate goods, intersectoral linkages through intermediate goods, and factor incomes at the industry level. The benchmark input-output (IO) tables published by the Bureau of Economic Analysis (BEA) offer most of this information. When necessary, we use additional data from the BEA, the Bureau of Labor Statistics (BLS), and the U.S. Department of Agriculture (USDA).

\footnotetext{
${ }^{1}$ The methodology we will develop in this paper works equally well for any other sector choice.
} 
We start by measuring the capital and labor shares in industry value added. The capital and labor shares of the model sectors are then the aggregates of the shares in the industry outputs that belong to this sector, both as intermediate inputs and as value added. We show how to carry out this aggregation with the help of the Industry-by-Commodity Total Requirements Matrix published by the BEA. ${ }^{2}$ We find that the capital shares differ across sectors. The largest capital share is in agriculture, followed by manufactured consumption, services, equipment, and construction. Moreover, the capital share of agriculture is more than two times that of construction and more than $50 \%$ larger than that of the aggregate economy.

We also aggregate our five sectors to measure the capital shares of the common two-sector splits. We find that the capital share is larger in agriculture than in nonagriculture, larger in consumption than in investment, and larger in tradables than nontradables. Our finding about the capital shares of consumption and investment confirms what Chari et al. (1996) and Huffman and Wynne (1999) found. Our finding about the capital shares in tradables and nontradables confirms the claim Obstfeld and Rogoff (1996) made in chapter 4 and it contradicts the claim of Stockman and Tesar (1995). If we value U.S. exports and imports both at the port of respective exit, we also find that exports have a larger capital share than imports.

We go beyond measuring the capital and labor income shares at the sectoral level and ask why agriculture has the largest capital share. The likely reason is that it has the largest land share. Since we are not aware of hard estimates of the land shares for our five model sectors, we provide such estimates by decomposing the sector capital shares into the factor shares of land, structures, and equipment. To achieve this, we combine data from the BEA, the BLS, and the USDA with information from Davis and Heathcote (2004) about the market value of residential land, the replacement cost of residential structures, and the price indices for residential land and residential structures. We find that, indeed, the land share in agriculture is larger than in other sectors. Furthermore, if we take the land share out, then the remaining capital share in agriculture is close to the economy-wide average.

\footnotetext{
${ }^{2}$ Total requirements matrices show the relationship between final uses and gross output. The Industry-byCommodity Total Requirements Matrix shows the production values required by the different industries to deliver a unit of each commodity to final users.
} 
It is common practice to use the economy-wide capital share as an approximation for the sector shares. Our findings show that the sector factor shares are different from the aggregate capital share. This suggests that users of multi-sector models who abstract from the differences in sector capital shares should make sure that this does not drive their results.

Our work is closely related to that of Bernanke and Gürkaynak (2001) and Gollin (2002), who found that across countries the aggregate capital shares average about one third and are uncorrelated with income. To split proprietors' income, we use a similar methodology as they did. It is reassuring that we find the same aggregate capital share for the U.S. as they did. Our work is also related that of Bentolila and Saint-Paul (2003), Young (2006), and Zuleta and Young (2007), who studied the evolution of the labor share at the industry level. Specifically Bentolila and Saint-Paul (2003) looked at the labor shares in the value added of the 13 industries in the business sectors in 12 OECD countries during 1972-93 and Young (2006) and Zuleta and Young (2007) looked at the labor shares of 35 industries' value added in the U.S. during 195896. In other words, these studies focussed on the factor shares in industry value added and so they had nothing to say about the factor shares at the sectoral level on which we focus here.

The paper is organized as follows. In section 2, we explain the mapping between multisector models and the data. In Sections 3 and 4, we measure the capital shares in industry value added and in the final output of the model sectors. In Section 5, we split the capital shares into the shares of land, structures, and equipment. Section 6 discusses the robustness of our findings and offers three extensions. Section 7 concludes.

\section{The Mapping Between Multi-Sector Models and the Data}

Applied economists often assume that the sectoral production functions are similar to the aggregate production functions. Perhaps the most common assumption is that sector j's output is produced from the primary production factors capital and labor according to a Cobb-Douglas production function:

$$
\frac{y_{j}}{p_{j}}=A_{j} k_{j}^{\theta_{j}} h_{j}^{1-\theta_{j}}
$$


Here $y_{j}$ denotes the dollar expenditures on the output of sector $j$ and $p_{j}$ denotes its price, so $y_{j} / p_{j}$ is the real output of sector $j$. Moreover, $A_{j}$ denotes total factor productivity in sector $j, k_{j}$ capital, $h_{j}$ labor, and $\theta_{j}$ the capital share.

This paper is about the values of $\theta_{j}$ where $j \in\{A, M, S, E, C\}$ and the five letters stand for agriculture, manufactured consumption, services, equipment, and construction. As most standard aggregate production functions, the sectoral production function (1) does not have intermediate inputs. For aggregate production functions, the justification is obvious because ultimately intermediate inputs are produced from the primary production factors capital and labor. ${ }^{3}$ For sectoral production functions, the justification is more involved because intermediate goods used in a sector are typically produced in other sectors, which themselves use intermediate goods produced in yet other sectors. In other words, as illustrated by the figure in Appendix A.1, the use of intermediate goods leads to a whole chain of intersectoral linkages that we have to take into account. Writing a sectoral production function of the form (1) implicitly assumes that capital and labor are reallocated among the sectors in such a way that each sector itself produces the intermediate inputs it uses directly or indirectly. The capital shares $\theta_{j}$ then reflect the capital inputs in the production of sector j's value added and in all intermediate inputs used directly or indirectly by sector $\mathrm{j}$.

The previous discussion implies that measuring sector factor shares requires information about value added and about intermediate inputs used directly or indirectly. The benchmark IO tables published by the BEA offer this information at the three or four-digit industry level. In order to employ them, we need to establish a mapping between the industries of the IO tables and the five model sectors. This is challenging not only because of the interindustry linkages, but also because industries often produce more than one good, different industries produce the same good, and most industries produce both final and intermediate goods. ${ }^{4}$ The figure in Appendix A.1 illustrates this in a stylized way.

One might think that we could also bring to bear other data sources such as the national income and product accounts (NIPA). Unfortunately these data sources do not tell us where

\footnotetext{
${ }^{3}$ Most applications abstract from imported intermediate inputs.

${ }^{4}$ Total industry output equals the final output and the intermediate goods produced in the industry.
} 
intermediate inputs are produced and where they are used. Without this information, we cannot take into account the interindustry linkages that the use of intermediate inputs implies.

The key concepts for mapping industries of the IO tables into the sectors of our model are the Use and the Make Matrix as described by the United Nations Statistics Division's System of National Accounts 1993. ${ }^{5}$ To explain their roles, we use the language and the notation of the BEA to the extent possible. Let there be $z$ commodities and $n$ industries. Let $\boldsymbol{B}$ denote the $(z \times n)$ Use Matrix. ${ }^{6}$ Rows are associated with commodities and columns with industries: entry $i j$ shows the dollar amount of commodity $i$ that industries $j$ uses per dollar of output it produces. Let $\boldsymbol{W}$ denote the $(n \times z)$ Make Matrix. Rows are associated with industries and columns with commodities: entry $i j$ shows for industry $i$ which share of one dollar of commodity $j$ it produces. Let $\boldsymbol{q}$ denote the $(z \times 1)$ commodity output vector. Each element records the sum of the dollar amounts of a given commodity that are delivered to final uses and to other industries as intermediate inputs. Let $\boldsymbol{g}$ denote the $(n \times 1)$ industry output vector. Element $i$ records the dollar amount of output of industry $i$. Lastly, let $\boldsymbol{e}$ denote the $(z \times 1)$ vector of dollar expenditure for final uses. Element $i$ records the final uses of commodity $i$.

Two identities link these matrices and vectors:

$$
\begin{aligned}
& q=B g+e, \\
& g=W q .
\end{aligned}
$$

The first identity says that the dollar output of each commodity equals the sum of the intermediate goods used by the different industries plus the final uses of that commodity. The second identity says the dollar output of each industry equals the sum of that industry's contribution to the outputs of the different commodities. To eliminate $\boldsymbol{q}$ from these identities, we substitute (3) into (2) to obtain $\boldsymbol{q}=\boldsymbol{B} \boldsymbol{W} \boldsymbol{q}+\boldsymbol{e}$. We then solve this expression for $\boldsymbol{q}$ and substitute the result back into (3). This gives:

$$
\boldsymbol{g}=\boldsymbol{W}(\boldsymbol{I}-\boldsymbol{B W})^{-1} \boldsymbol{e} .
$$

\footnotetext{
${ }^{5}$ For further explanation see ten Raa (2005) and Bureau of Economic Analysis (2006). For a critical discussion of the methodology used see Krueger (1999).

${ }^{6}$ Matrices and vectors are in boldface throughout the paper.
} 
$\boldsymbol{W}(\boldsymbol{I}-\boldsymbol{B} \boldsymbol{W})^{-1}$ is called the Industry-by-Commodity Total Requirements Matrix. Rows are associated with industries and columns with commodities. Entry $i j$ shows the dollar value of industry $i$ 's production that is required, both directly and indirectly, to deliver one dollar of commodity $j$ to final use. The BEA publishes this matrix ready for us to use.

We now turn to the five model sectors. Let the vectors $\boldsymbol{y}_{\boldsymbol{j}}$ record the final dollar expenditures on the commodities that belong to sector $j \in\{A, M, S, E, C\}$. We will explain in section 4 below how we obtain these vectors. For now, let us assume that we have them already. The dollar value of sector $j$ 's output is then given by $y_{j}=\mathbf{1}^{\prime} \boldsymbol{y}_{j}$ and the dollar value of GDP is given by $y=\mathbf{1}^{\prime} \boldsymbol{e}$ where $\mathbf{1}^{\prime}$ is a row vector of ones.

We are now ready to establish the relationship between the sector capital shares $\theta_{j}$ we are after and the industry capital and labor incomes that we can measure using the IO table. We begin by noting that the vector $\boldsymbol{W}(\boldsymbol{I}-\boldsymbol{B} \boldsymbol{W})^{-1} \boldsymbol{y}_{j}$ tells us how much of each industry's output is required to produce the final expenditure vector $\boldsymbol{y}_{j}$. Let $\alpha_{k i}$ and $\alpha_{h i}$ denote the capital and labor income generated per unit of industry $i$ 's output $g_{i}$. In order to obtain all payments to capital that result from the production of the expenditure vector $\boldsymbol{y}_{j}$, we need to multiply the payments to capital per unit of industry output with the required industry outputs, sum up and divide the result by the total payments to capital and labor:

$$
\theta_{j}=\frac{\boldsymbol{\alpha}_{\boldsymbol{k}}{ }^{\prime} \boldsymbol{W}(\boldsymbol{I}-\boldsymbol{B} \boldsymbol{W})^{-1} \boldsymbol{y}_{j}}{\left(\boldsymbol{\alpha}_{\boldsymbol{k}}{ }^{\prime}+\boldsymbol{\alpha}_{\boldsymbol{h}}{ }^{\prime}\right) \boldsymbol{W}(\boldsymbol{I}-\boldsymbol{B} \boldsymbol{W})^{-1} \boldsymbol{y}_{j}}
$$

Recall that the BEA offers the matrix $\boldsymbol{W}(\boldsymbol{I}-\boldsymbol{B W})^{-1}$. So, we only need to measure the capital and labor incomes $\alpha_{k}$ and $\alpha_{h}$ per unit of industry outputs and we need to construct the final expenditure vectors $\boldsymbol{y}_{\boldsymbol{j}}$ for the model sectors. We do this in sections 3 and 4 below.

We should mention that expression (5) works for any final expenditure vector, not just for $\boldsymbol{y}_{j}$ with $j \in\{A, M, S, E, C\}$. For example, to obtain the capital share in GDP, we just use the vector $\boldsymbol{e}$ of total final expenditure:

$$
\theta=\frac{\boldsymbol{\alpha}_{k}{ }^{\prime} \boldsymbol{W}(\boldsymbol{I}-\boldsymbol{B} \boldsymbol{W})^{-1} \boldsymbol{e}}{\left(\boldsymbol{\alpha}_{k^{\prime}}+\boldsymbol{\alpha}_{\boldsymbol{h}^{\prime}}\right) \boldsymbol{W}(\boldsymbol{I}-\boldsymbol{B} \boldsymbol{W})^{-1} \boldsymbol{e}}
$$




\section{Income Shares of Capital in Industry Value Added in the}

\section{Data}

In this section, we measure the components of the vectors $\alpha_{k}$ and $\alpha_{h}$. This involves measuring the capital and labor incomes in industry value added and dividing them by industry output. We employ the most recent benchmark IO tables, which are from 1997 and contain four-digit industry data. The IO tables break down industry value added into indirect business tax and nontax liabilities, compensation of employees, and gross operating surplus (or other value added). Note that the category indirect business tax and nontax liabilities contains subsidies. Note too that gross operating surplus is calculated as the residual after indirect taxes and nontax liabilities have been paid and labor has been compensated, so by construction it contains depreciation.

Under perfect competition, the share parameters of the sectoral production functions (1) equal the income shares of capital and labor in output net of indirect taxes and nontax liabilities. $^{7}$ We therefore subtract indirect taxes and nontax liabilities from industry value added and measure the payments to labor and capital in the resulting net value added. The entire compensation of employees unambiguously is labor income and gross operating surplus minus proprietors' income unambiguously is capital income. In contrast, proprietors' income (or other gross operating surplus - noncorporate) has a capital and a labor component. For example, if a restaurant owner manages his restaurant, then he is a proprietor who receives income from both the capital he owns (kitchen equipment, bar, furniture, etc.) and the labor he puts in. This presents us with two questions: Which part of each industry's gross operating surplus is proprietors' income? Which part of each industry's proprietors' income is capital income?

Since the IO tables do not report proprietors's income, we turn to the GDP-By-Industry Tables of the BEA. These tables report proprietors' income at the two-digit level of the Standard Industrial Classification (henceforth SIC) for 1997 broken down into the following four cate-

\footnotetext{
${ }^{7}$ This is not the case when wages are determined through collective wage bargaining as in many European countries; see Bentolila and Saint-Paul (2003) for further discussion. Since our focus here is the U.S. where unions are relatively weak, we use the benchmark perfect competition.
} 
gories: Proprietors' Income without Inventory Valuation Adjustment and Capital Consumption Adjustment; Rental Income of Persons without Capital Consumption Adjustment; Proprietors' Income Inventory Valuation Adjustment; Capital Consumption Allowance, Noncorporate Business, and Consumption of Fixed Capital, Housing and Nonprofit Institutions Serving Households. The first two categories have both capital and labor income components, whereas the last two categories belong entirely to capital income. With some abuse of the language, we call the sum of the first two components proprietors' income from now on.

Before we can calculate the share of proprietors' income in gross operating surplus, we need to address that the GDP-by-Industry Table report owner-occupied housing as part of the real estate industry whereas the IO tables report owner-occupied housing separately. Thus, we have to split rental income into the part coming from owner-occupied housing and the part coming from the real estate industry. We calculate the rental income of owner-occupied housing as a fraction of total rental income using data for 1997 from Table 7.9., Rental Income of Persons by Legal Form of Organization and by Type of Income of the BEA. The rental income for owner-occupied housing then follows as the product of this ratio and the total rental income in the GDP-by-Industry Table. The rental income for the real estate industry without owneroccupied housing follows as the residual.

Since the value added data in the IO tables is at the four-digit level using the NAICS industry classification whereas in the GDP-by-Industry Table is two-digit level using the SIC industry classification, we need to map these two tables into each other. We do this in the natural way by assigning to each four-digit industry of the IO tables the proprietors' income share for 1997 of the corresponding two-digit industry in the GDP-by-Industry Table. In doing so, we follow the guide of the U.S. Census Bureau about mapping SIC industry codes into NAICS codes.

To answer which part of each industry's proprietors' income is capital income, we adopt Gollin's (2002) economy-wide assumption at the industry level. Specifically, we first calculate the share of capital income in the industry's value added minus proprietors' income. We then assume that this capital share also applies to the industry's proprietors' income. Formally, this 
gives: ${ }^{8}$

$$
\begin{aligned}
\alpha_{k i} & \equiv\left(\operatorname{gos}_{i}-\frac{\operatorname{com}_{i}}{\operatorname{com}_{i}+\operatorname{gos}_{i}-\text { pro }_{j(i)}} \text { pro }_{j(i)}\right) \frac{1}{g_{i}}, \\
\alpha_{h i} & \equiv\left(\operatorname{com}_{i}+\frac{\operatorname{com}_{i}}{\operatorname{com}_{i}+\operatorname{gos}_{i}-\text { pro }_{j(i)}} \operatorname{pro}_{j(i)}\right) \frac{1}{g_{i}} .
\end{aligned}
$$

Recall from the previous section that $\alpha_{k i}$ and $\alpha_{h i}$ are the capital and labor income per unit of industry $i$ 's output $g_{i}$. The new symbols are gos $_{i}$ and $\operatorname{com}_{i}$, which stand for gross operating surplus and the compensation of employees of industry $i$. Moreover, $\operatorname{pro}_{j(i)}$ denotes the proprietors' income in the two-digit industry $j(i)$ that corresponds to the four-digit industry $i$.

Many authors use the capital shares in industry value added as proxies for the capital shares in final uses of industry output. In this paragraph, we digress slightly and evaluate how good this approximation is. The capital share in industry value added just equals $\alpha_{k i} g_{i} /\left(\operatorname{com}_{i}+\operatorname{gos}_{i}\right)$ with $\alpha_{k i}$ given in (6). The capital share in final uses of industry output follows from formula (5) with the vector $\boldsymbol{y}_{j}$ replaced by the vector of final uses produced by industry $i$. Figure 1 plots the result where quantities are in producer prices. The key finding is that industries with capital shares in value added close to the economy-wide capital shares of 0.33 have capital shares in final uses close to 0.33 . In contrast, industries with capital shares in value added below (above) the economy-wide capital share tend to have higher (lower) capital shares in final uses of industry output than in value added. The fact that there is a systematic difference between the two capital shares implies that taking the former as an approximation for the latter leads to systematic errors. This suggest that our exercise has some merit. ${ }^{9}$

\footnotetext{
${ }^{8}$ In Section 6.1 below, we will establish that our findings would not change much if we used instead the BLS estimates for the capital and labor shares of proprietors' income. Since these estimates are not publically available though, we do not to use them in the main part of the paper.

${ }^{9} \mathrm{~A}$ possible explanation for the systematic difference is that most industries use a broad set of intermediate inputs that together have an average capital share close to the economy-wide capital share.
} 
Figure 1

Capital income shares in industry value added and in final uses of industry output (in producer prices)

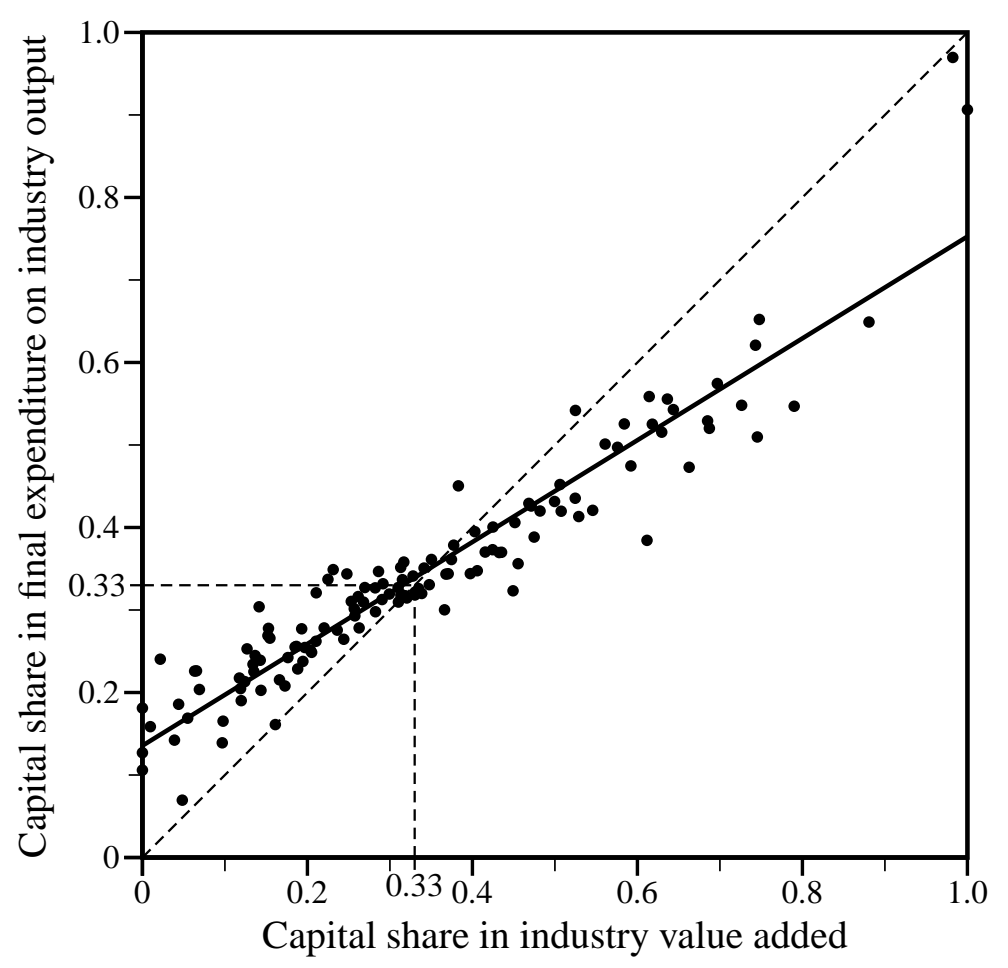

\section{Income Shares of Capital at the Sectoral Level}

In this section, we construct the final expenditure vectors $\boldsymbol{y}_{j}$ of our five model sectors. Recall that the entry $i$ of vector $\boldsymbol{y}_{j}$ reports the expenditures on final uses of commodity $i$ that belong to sector $j$ with $j \in\{A, M, S, E, C\}$. Sector output $j$ 's output follows by summing the components of $\boldsymbol{y}_{j}: y_{j}=\mathbf{1}^{\prime} \boldsymbol{y}_{j}$

We first construct the four sectors nontradable consumption (services), nontradable investment (construction), tradable consumption (agriculture plus manufactured consumption), and tradable investment (equipment). We then split tradable consumption into agriculture and manufactured consumption. In order to construct the four sectors, we need to identify in the data whether a delivery of a commodity to final uses is for consumption or investment purposes and whether that commodity is tradable or nontradable. 
We start with consumption and investment. The consumption vector contains all final uses of each commodity for consumption purposes and the investment vector contains all final uses of each commodity for fixed investment (personal and government) and changes in private inventories. The sum of the components of each of these two vectors add up to the total consumption and investment expenditures. We emphasize that most industries deliver to final uses for both consumption and investment purposes, as the figure in Appendix A.1 illustrates. For example, cars sold to firms are counted as investment whereas cars sold to consumers are counted as consumption. Consequently, there is no sense in which entire industries are consumption or investment industries and so the consumption and investment sectors will not correspond to mutually exclusive sets of industries.

The BEA does not split net exports between consumption and investment. We assume that the consumption and investment shares in the net exports of a commodity equal the consumption and investment shares in the not exported output of the commodity. This splits GDP into consumption and investment.

We continue by splitting GDP into nontradables and tradables. ${ }^{10}$ We assume that nontradable investment equals the deliveries to investment of all commodities classified as construction (two-digit code 23) and tradable investment equals the deliveries to investment of all other commodities. We assume that nontradable consumption equals government consumption and the deliveries to consumption of utilities (two-digit code 22) and services (three-digit codes larger or equal to 420). We assume that all other deliveries to consumption are tradable. The tradable sector constructed in this way produces $81 \%$ of all commodities that the U.S. actually exports and $99 \%$ of the commodities that the U.S. actually imports. The discrepancy comes from the fact that the U.S. also exports services, which for lack of better information we have classified as nontradable here.

Lastly, we split tradable consumption into agriculture and manufactured consumption. We assume that agriculture is tradable consumption expenditures on commodities with a two-digit

\footnotetext{
${ }^{10}$ To avoid confusion, note that exports and imports refer to the goods the U.S. actually trades with the rest of the world whereas tradables refer to the goods the U.S. can in principle trade with the rest of the world.
} 
code 11. Manufactured consumption is the remaining expenditures on tradable consumption. ${ }^{11}$

This completes the construction of the five final expenditure vectors $\boldsymbol{y}_{j}, j \in\{a, m, s, e$, c), so we now have all components of the right-hand side of expression (5). Before we can calculate sector capital shares, we need to decide whether they should be in producer prices or in purchaser prices. A quantity in purchaser prices equals the quantity in producer prices plus the distribution costs for this quantity. This holds for all commodities except distribution services. Distribution services include transportation costs (i.e. rail, truck, water, air, pipe and gas pipe transportation) and trade margins (i.e. wholesale and retail trade). The BEA reports all of these categories for each final use vector and for each commodity. The Use Matrix in purchaser prices treats distribution costs as intermediate inputs. In contrast, the Use Matrix in producer prices treats distribution costs as final expenditures on distribution services that are reported as part of the final output of the transport industries and the trade industries. In this section we report sector capital shares in producer prices. In subsection 6.3, we will report capital shares in purchaser prices.

Table 1 reports our findings on capital income shares in producer prices. The largest capital share is in agriculture, followed by manufactured consumption, services and equipment investment, and construction. Moreover the differences between these sector capital shares are sizeable: the capital share in agriculture is more than two and a half times that of construction and more than 50\% larger than that of the aggregate economy. Table 1 also reports the capital shares when we aggregate the sectors to the three most common multi-sector splits. First, agriculture is more capital intensive than non-agriculture. Second, consumption is more capital intensive than investment. This confirms the findings of Chari et al. (1996) and Huffman and Wynne (1999). Huffman and Wynne (1999) took the short cut of categorizing entire industries as either consumption or investment. Chari et al. (1996) followed similar steps as we do to construct the consumption and investment sectors. ${ }^{12}$ Third, tradables are more capital intensive than nontradables, which confirms the claim of chapter 4 of Obstfeld and Rogoff (1996) and

\footnotetext{
${ }^{11}$ Note that the agricultural industries also produce some tradable investment, typically in the form of inventories of agricultural goods.

${ }^{12}$ This is explained in an unpublished appendix, which brought to our knowledge after we had submitted the first version of our paper.
} 
Table 1

Capital income shares at the sectoral level (in producer prices)

\begin{tabular}{l|l}
\hline Agriculture (A) & 0.54 \\
Manufactured consumption (M) & 0.40 \\
Services (S) & 0.34 \\
Equipment investment (E) & 0.34 \\
Construction investment (C) & 0.21 \\
\hline Agriculture (A) & 0.54 \\
Manufacturing (M+E+C) & 0.33 \\
Services (S) & 0.34 \\
\hline Consumption (A+M+S) & 0.35 \\
Investment (E+C) & 0.28 \\
\hline Tradables (A+M+E) & 0.37 \\
Nontradables (S+C) & 0.32 \\
\hline Agriculture (A) & 0.54 \\
Nonagriculture (M+S+E+C) & 0.33 \\
\hline GDP (A+M+S+E+C) & 0.33 \\
\hline
\end{tabular}


contradicts the claim of Stockman and Tesar (1995).

Two features of our findings deserve further discussion. First, the capital share in construction comes out very low, making construction by far the most labor-intensive sector. Construction in the U.S. has traditionally been among the most unionized industries. According to the Census, average hourly wages in construction are somewhat larger than in comparable industries such as manufacturing and in transportation and warehousing. ${ }^{13}$ Our assumption of competitive factor markets may therefore be a bit of a stretch for the construction industry. Second, the largest capital share is in agriculture. Given that capital comprises land (in addition to equipment and structures), the reason may be that agriculture has a large land share. We are going to explore this possibility now.

\section{Income Shares of Land, Structures, and Equipment in the}

\section{Model Sectors}

Our aim in this section is to break down the sector income shares of capital into the sector income shares of land, structures, and equipment. To achieve this, we need to break down the capital income $\alpha_{k i}$ generated per unit of each industry $i$ 's output $g_{i}$ into $\alpha_{l i}, \alpha_{b i}$, and $\alpha_{e i}{ }^{14}$ Applying the same logic that underlies expression (5), this gives expressions for the income shares of land, structures, and equipment for our five model sectors $j \in\{A, M, S, E, C\}$ :

$$
\begin{aligned}
\theta_{l j} & =\frac{\boldsymbol{\alpha}_{\boldsymbol{l}}{ }^{\prime} \boldsymbol{W}(\boldsymbol{I}-\boldsymbol{B} \boldsymbol{W})^{-1} \boldsymbol{y}_{j}}{\left(\boldsymbol{\alpha}_{\boldsymbol{k}}{ }^{\prime}+\boldsymbol{\alpha}_{\boldsymbol{h}}{ }^{\prime}\right) \boldsymbol{W}(\boldsymbol{I}-\boldsymbol{B} \boldsymbol{W})^{-1} \boldsymbol{y}_{j}}, \\
\theta_{b j} & =\frac{\boldsymbol{\alpha}_{\boldsymbol{b}}{ }^{\prime} \boldsymbol{W}(\boldsymbol{I}-\boldsymbol{B} \boldsymbol{W})^{-1} \boldsymbol{y}_{j}}{\left(\boldsymbol{\alpha}_{\boldsymbol{k}}{ }^{\prime}+\boldsymbol{\alpha}_{\boldsymbol{h}}{ }^{\prime}\right) \boldsymbol{W}(\boldsymbol{I}-\boldsymbol{B} \boldsymbol{W})^{-1} \boldsymbol{y}_{j}}, \\
\theta_{e j} & =\frac{\boldsymbol{\alpha}_{\boldsymbol{e}}{ }^{\prime} \boldsymbol{W}(\boldsymbol{I}-\boldsymbol{B} \boldsymbol{W})^{-1} \boldsymbol{y}_{j}}{\left(\boldsymbol{\alpha}_{\boldsymbol{k}}{ }^{\prime}+\boldsymbol{\alpha}_{\boldsymbol{h}}{ }^{\prime}\right) \boldsymbol{W}(\boldsymbol{I}-\boldsymbol{B} \boldsymbol{W})^{-1} \boldsymbol{y}_{j}},
\end{aligned}
$$

where we used that $\alpha_{k i}=\alpha_{l i}+\alpha_{b i}+\alpha_{e i}$.

\footnotetext{
${ }^{13}$ The data is at http://www.census.gov/compendia/statab/tables/07s0618.xls. We thank a referee for pointing this out to us.

${ }^{14}$ Note that we use the subscript $b$ (as in buildings) for structures because the subscript $s$ is already taken for services.
} 
The BEA does not report $\alpha_{l i}, \alpha_{b i}$, and $\alpha_{e i}$. We therefore turn to the Capital Income (CI) table of the BLS, which reports the incomes of land, structures, equipment, and inventories for all business industries at the three-digit level. We group inventories together with equipment and call the resulting category equipment. To decompose $\alpha_{k i}$ at the four-digit industry level, we assume that the composition of capital income in the four-digit industry $i$ in the IO tables is the same as in the corresponding three-digit industry $j(i)$ in the CI table, so we have: ${ }^{15}$

$$
\begin{aligned}
& \alpha_{l i}=\frac{\alpha_{l j(i)}}{\alpha_{k j(i)}} \alpha_{k i}, \\
& \alpha_{b i}=\frac{\alpha_{b j(i)}}{\alpha_{k j(i)}} \alpha_{k i}, \\
& \alpha_{e i}=\frac{\alpha_{e j(i)}}{\alpha_{k j(i)}} \alpha_{k i} .
\end{aligned}
$$

This general procedure works for all but seven industries. The first special case is the farm sector with its two industries animal production and crop production. The BLS attributes the income from rented farm land to the farm sector whereas the IO tables attribute it to the real estate sector, (from which the farm sector is assumed to rent the land). We therefore need to change the CI table and take the income from rented farm land out of the farm sector. The second special case is owner-occupied housing, which the BEA has as part of the service sector. ${ }^{16}$ Since the BLS restricts its attention to the business sector, it does not cover income from owner-occupied housing. We therefore need to impute the capital incomes in owneroccupied housing. The third special case is real estate. The first adjustment here is that we need to include the income from rented farm land. The second adjustment is that we need to split what the BLS calls "rental residential capital" into land, structures, and equipment. The last special case is the government sector with its three industries Government Enterprises, State and Local Government Enterprises, and General Government Industry. Again the BLS does not cover these industries because they are not part of the business sector.

We start with the first special case which requires us to take the income from rented farm

\footnotetext{
${ }^{15} \mathrm{http} / / / \mathrm{www} \cdot b l s . g o v / \mathrm{mfp} / \mathrm{home} \cdot \mathrm{htm}$ offers details about the data and how they are constructed. ftp://ftp.bls.gov/pub/special.requests/opt/mp/prod3.capital.zip offers the database itself.

${ }^{16}$ Note that the BEA uses the term owner-occupied dwellings instead of owner-occupied housing.
} 
land in the CI table out of the farm sector. To do so, we impute the income from the farm sector's owned land. The 1997 Census of Agriculture of USDA reports that the ratio of owned land in farms to rented or leased land in farms equals 1.46. In Table 7.3.5, Farm Sector Output, Gross Value Added, and Net Value Added, the BEA reports the income from rented land as rent paid to nonoperator landlords. Assuming that the rents on owned and rented farm land are the same, we have: ${ }^{17}$

imputed rent paid to operator landlords

$$
=\text { rent paid to nonoperator landlords } \frac{\text { owned farm land }}{\text { rented or leased farm land }} \text {. }
$$

Dividing the imputed rent paid to operator landlords by farm output, we obtain an estimate $\alpha_{l, f a}$ for the land income in the farm sector. This estimate implies a land share in gross output of the farm sector equal to 0.14 , which is close to what Mundlak (2005) reports. Since the BLS reports the other two factor shares $\alpha_{e, f a}$ and $\alpha_{b, f a}$, we have all components of the capital share in farm output. As before, we assume that the composition of the capital shares in the two farm industries is the same as in the farm sector as a whole. This gives the following expressions for the capital shares in output of the two farm industries $i \in\{c r, a n\}$ :

$$
\begin{aligned}
\alpha_{l i} & =\frac{\alpha_{l, f a}}{\alpha_{k, f a}} \alpha_{k i}, \\
\alpha_{b i} & =\frac{\alpha_{b, f a}}{\alpha_{k, f a}} \alpha_{k i}, \\
\alpha_{e i} & =\frac{\alpha_{e, f a}}{\alpha_{k, f a}} \alpha_{k i} .
\end{aligned}
$$

We continue with the second special case of owner-occupied housing. Since the BLS restricts its attention to the business sector, we turn to Davis and Heathcote (2004), who offer estimates of land, structures, and prices for nonfarm housing. Nonfarm housing is comprised of owner-occupied housing and tenant-occupied housing whereas the housing sector is comprised

\footnotetext{
${ }^{17}$ The Agricultural Land Survey, which is the part of the Agricultural Census, reports the aggregate of land and structures for owned farm land and for rented farm land. We also imputed the rents from owned farm land by using these data. The results were very similar.
} 
of nonfarm and farm housing. Since there is little equipment in housing, we assume it away. This implies that the capital stock in housing is comprised of land and structures only. We use the data of Davis and Heathcote to estimate the capital shares of land and structures per unit of nonfarm housing. We then assume that the composition of the capital shares in owner-occupied housing s the same as in nonfarm housing:

$$
\begin{aligned}
\alpha_{l, o o h} & =\frac{\alpha_{l, n f h}}{\alpha_{k, n f h}} \alpha_{k, o o h}, \\
\alpha_{b, o o h} & =\frac{\alpha_{b, n f h}}{\alpha_{k, n f h}} \alpha_{k, o o h}, \\
\alpha_{e, o o h} & =0 .
\end{aligned}
$$

Given the assumption of a zero equipment share in housing, the income shares of total capital and land in the output of nonfarm housing imply the income share of structures. Thus, we only need to estimate the income share of land. To this end, we impose a no-arbitrage condition between the net returns on land and structures in the nonfarm housing. Assuming a Cobb-Douglas technology, the no-arbitrage condition takes the form

$$
\frac{\alpha_{l, n f h} g_{n f h}}{l_{n f h}}-\delta_{l, n f h}+\frac{\Delta p_{l, n f h}}{p_{l, n f h}}=\frac{\alpha_{b, n f h} g_{n f h}}{b_{n f h}}-\delta_{b, n f h}+\frac{\Delta p_{b, n f h}}{p_{b, n f h}}
$$

where $n f h$ stands for the nonfarm housing sector. Moreover, $g_{n f h}$ is the value of the output, $l_{n f h}$ and $b_{n f h}$ are the values of land and structures, $\alpha_{l, n f h}$ and $\alpha_{b, n f h}$ are the income shares, $\delta_{l, n f h}$ and $\delta_{b, n f h}$ are the depreciation rates, and $p_{l, n f h}$ and $p_{b, n f h}$ are the prices of land and structures. Assuming constant returns in addition and maintaining that the equipment share is zero, the income shares of land, structures, labor, and intermediate inputs in the nonfarm housing sector add up to one:

$$
\alpha_{l, n f h}+\alpha_{b, n f h}+\alpha_{h, n f h}+\alpha_{z, n f h}=1
$$

We will now explain how to measure the unknowns in (20) except for $\alpha_{l, n f h}$. We then solve for 
$\alpha_{l, n f h}$.

We estimate the output $g_{n f h}$ of nonfarm housing from data provided by the BEA on output and value added of owner-occupied housing and tenant-occupied housing (Table 7.4.5. Housing Sector Output, Gross Value Added, and Net Value Added). Davis and Heathcote (2004) provide estimates of the market value of residential land, $l_{n f h}$, and the replacement cost of residential structures, $b_{n f h}$. They also provide estimates of the price indices. We calculate the average values from their data between 1990 and 2000, which gives $g_{n f h} / l_{n f h}=0.147$, $g_{n f h} / b_{n f h}=0.097, \Delta p_{l, n f h} / p_{l, n f h}=0.034$, and $\Delta p_{b, n f h} / p_{b, n f h}=0.031$. We obtain the depreciation rate of housing structures from the Investment and Net Fixed Asset Data on Residential Structures at Constant Prices by taking the 1990-2000 average of $\delta_{b, n f h}=\left(i_{b, n f h}-\Delta b_{n f h}\right) / b_{n f h}$, which gives $\delta_{b, n f h}=0.016$. Land does not depreciate, so we set $\delta_{l, n f h}=0$. The BEA publishes the intermediate inputs to output ratio in nonfarm housing. The average for 1990-2000 is $\alpha_{z, n f h}=0.185$. Similarly the average for $1990-2000$ of the labor income to output ratio is $\alpha_{h, n f h}=0.014$. These are all the unknowns in (20) except for $\alpha_{l, n f h}$. Solving we find $\alpha_{l, n f h}=0.24$. Note that (20) and these numbers imply a 7\% nominal net rate of return. Given that average consumer price inflation from 1990-2000 was $2.4 \%$, the implied real rate of return is $4.6 \%$, which close to standard values.

We now turn to the third special case, notably the real estate industry. The CI table of the BLS splits the income attributed to the real estate industry into land, structures, equipment, inventories, and rental residential capital. Rental residential capital is a bundle of structures and land corresponding to tenant-occupied housing. As before, we group inventories together with equipment. We split rental residential capital into structures and land using the shares we calculated above for nonfarm housing. Thus, we have the incomes of land, structures, and equipment per unit of output in real estate in the CI table. We apply these income shares to the data in the IO tables by assuming that the composition of the capital income in real estate excluding rents paid to nonoperator landlords in the IO tables is the same as the capital income in real estate including rental residential capital in the $\mathrm{CI}$ table. The shares for farm land are the ones we measured in the first special case above. 
Table 2

Income shares of land, structures, and equipment at the sectoral level (in producer prices)

\begin{tabular}{l|c|ccc}
\hline & Capital & Land & Structures & Equipment \\
\hline Agriculture (A) & 0.54 & 0.18 & 0.14 & 0.22 \\
Manufactured consumption (M) & 0.40 & 0.04 & 0.11 & 0.25 \\
Services (S) & 0.34 & 0.06 & 0.15 & 0.13 \\
Equipment investment (E) & 0.34 & 0.03 & 0.09 & 0.22 \\
Construction investment (C) & 0.21 & 0.03 & 0.06 & 0.12 \\
\hline Agriculture (A) & 0.54 & 0.18 & 0.14 & 0.22 \\
Manufacturing (M+E+C) & 0.33 & 0.03 & 0.09 & 0.21 \\
Services (S) & 0.34 & 0.06 & 0.15 & 0.13 \\
\hline Consumption (A+M+S) & 0.35 & 0.06 & 0.15 & 0.14 \\
Investment (E+C) & 0.28 & 0.03 & 0.07 & 0.18 \\
\hline Tradables (A+M+E) & 0.37 & 0.04 & 0.10 & 0.23 \\
Nontradables (S+C) & 0.32 & 0.05 & 0.14 & 0.13 \\
\hline Agriculture (A) & 0.54 & 0.18 & 0.14 & 0.22 \\
Nonagriculture (M+S+E+C) & 0.33 & 0.05 & 0.13 & 0.15 \\
\hline GDP (A+M+S+E+C) & 0.33 & 0.05 & 0.13 & 0.15 \\
\hline
\end{tabular}


Lastly, we turn to the fourth special case, notably the government sector with its industries federal Government Enterprises, State and Local Government Enterprises, and General Government Industries. The BLS data do not cover these industries because they are not part of the business sector. We proceed by first splitting the capital income into the incomes of equipment and structures/land. We use data on the net fixed assets of the government available from the BEA in Table 11B of the Fixed Assets Series. For Federal Government Enterprises and State and Local Government Enterprises, we set the share of equipment in capital income equal to the 1997 ratio of equipment to total fixed assets of all Government Enterprises. For the General Government Industry, we set the share of equipment in capital income equal to the 1997 ratio of equipment to total nonresidential fixed assets of the government excluding fixed assets of Government Enterprises. Next we split the remaining capital income between structures and land. Since the three government industries essentially produce services, we assume that the income shares of structures and land equal those in the private service sector.

Table 2 reports our findings on the three capital incomes shares for the five sectors, for more aggregate sectors splits, and for the whole economy. Again the calculations are based on producer prices. Note that the sums of the shares of land, structures, and equipment in table 2 equal the capital shares in table 1 . As expected, we find that agriculture has by far the largest land share and that without land the capital share in agriculture is fairly close to the aggregate capital share. Moreover, the income shares of structures and equipment at the sectoral level also vary considerably.

\section{Extensions}

\subsection{Robustness}

So far, we have assumed that the capital and labor shares in proprietors' income equal the capital and labor shares in the industry's value added without proprietors' income. In this subsection, we use three-digit industry level data from the BLS on the capital income and the compensation of all persons to split proprietors' income in a different way. 
Table 3

Capital income shares at the sectoral level with different ways of splitting proprietors' income between capital and labor (in producer prices)

\begin{tabular}{l|cc}
\hline \multirow{2}{*}{} & \multicolumn{2}{|c}{ capital share in proprietors' income } \\
\cline { 2 - 3 } & $\begin{array}{c}\text { equals capital share in } \\
\text { industry value added without } \\
\text { proprietors' income }\end{array}$ & $\begin{array}{c}\text { is imputed } \\
\text { by BLS }\end{array}$ \\
\hline Agriculture (A) & 0.54 & 0.57 \\
Manufactured consumption (M) & 0.40 & 0.38 \\
Services (S) & 0.34 & 0.35 \\
Equipment investment (E) & 0.34 & 0.31 \\
Construction investment (C) & 0.21 & 0.25 \\
\hline Agriculture (A) & 0.54 & 0.57 \\
Manufacturing (M+E+C) & 0.33 & 0.32 \\
Services (S) & 0.34 & 0.35 \\
\hline Consumption (A+M+S) & 0.35 & 0.36 \\
Investment (e+b) & 0.28 & 0.28 \\
\hline Tradables (A+M+E) & 0.37 & 0.35 \\
Nontradables (S+C) & 0.32 & 0.34 \\
\hline Agriculture (A) & 0.54 & 0.57 \\
Nonagriculture (M+S+E+C) & 0.33 & 0.34 \\
\hline GDP (A+M+S+E+C) & 0.33 & 0.34 \\
\hline
\end{tabular}

The capital income data is publicly available from the BLS webside whereas the data on the compensation of all persons is available from the BLS upon request. The BLS generates these data by imputing the capital and labor parts of proprietors' income in the different industries; it then scales the capital and labor parts of each industry such that their sum equals that industry's proprietors' income. To use the BLS numbers, we assume that the proprietors's income composition of each four-digit industry in the IO tables of the BEA is the same as in the corresponding three-digit industry in the BLS data.

Table 3 reports the findings. For comparability column 2 also reports our previous results 
Factor shares in exports and imports

Table 4

\begin{tabular}{|c|c|c|c|c|}
\hline & \multicolumn{2}{|c|}{ Exports at port of exit in } & \multicolumn{2}{|c|}{ Imports at } \\
\hline & $\begin{array}{l}\text { producer } \\
\text { prices }\end{array}$ & $\begin{array}{c}\text { purchaser } \\
\text { prices }\end{array}$ & $\begin{array}{l}\text { port of } \\
\text { entry }\end{array}$ & $\begin{array}{c}\text { port of } \\
\text { exit }\end{array}$ \\
\hline Capital & 0.37 & 0.39 & 0.39 & 0.38 \\
\hline Land & 0.03 & 0.03 & 0.03 & 0.03 \\
\hline Structures & 0.09 & 0.10 & 0.12 & 0.11 \\
\hline Equipment & 0.25 & 0.26 & 0.24 & 0.24 \\
\hline
\end{tabular}

from table 1. Reassuringly, both methods of splitting proprietors' income give fairly similar capital shares at the sectoral level.

\subsection{Factor income shares of exports and imports and the Leontief para- dox}

Our methodology is suited for measuring the factor income shares of any final commodity vector. An important example is the commodity vectors of U.S. exports and imports. Since the U.S. does not produce its imports, the interpretation of the capital share of its imports is that this would be the capital share if all countries used the U.S. technology. Table 4 reports the factor shares in U.S. exports at producer and purchaser prices and in U.S. imports at the port of entry (U.S. port) and the port of exit (foreign port). The difference between domestic and foreign port values comes from customs duties, freight charges, and insurance. The domestic port value of imports is the same at producer and purchaser prices because imports have not yet been transported to domestic purchasers.

Table 4 has two important implications. First, no matter how we measure the capital shares of U.S. imports and exports, they are close to each other and close to the capital share of tradable goods, which we have found to be 0.37 . This gives additional confidence in the way in which we constructed our tradable sector. Second, depending on which measure we use the capital share of exports is either larger or smaller than the capital share of imports.

The second implication is important in light of the so called Leontief paradox. On his first 
visit to the U.S., Leontief (1954) measured the capital intensities of U.S. imports valued at the port of entry and U.S. exports valued in producer prices. To his surprise, he found that the capital-labor ratio of imports was $30 \%$ higher than that of exports. Repeating his exercise for 1951, he still found that capital-labor ratio of imports was $6 \%$ higher than that of exports. These findings are at odds with the predictions of standard Heckscher-Ohlin trade theory, which would have a capital abundant country like the U.S. export goods that are more capital intensive than its imports. A great many studies in international trade have since tried to resolve the paradox; see for example Leamer (1980).

We state our results in terms of factor income shares. If we assume, however, that the marginal product of capital and labor is the same across sectors, then differences in capital shares translate into differences in capital-labor ratios. If we follow Leontief and take exports at producer prices and imports at the port of entry, then we find U.S. imports to be 2 percentage points more capital intensive than U.S. exports. In contrast, if we measure exports at purchaser prices and imports at the port of exit (foreign port), then we find exports to be 1 percentage point more capital intensive than imports. In other words, whether there is a Leontief paradox in our 1997 data depends on where one values exports and imports. ${ }^{18}$

\subsection{Distribution costs as part of sector output}

In this subsection, we report sector capital shares in purchaser prices. This is useful because some data sets - such as the Penn World Tables - come in purchaser prices. The Use Matrix in purchaser prices treats the distribution costs as intermediate inputs in the different industries. Consequently, the distribution services required to deliver commodities to final uses become part of the industries' final outputs.

Table 5 reports the sector capital shares in purchaser prices. Comparing tables 2 and 5 , we can see that the capital shares of agriculture and manufactured consumption drop considerably when we include the distribution services in the sector outputs. The intuitive explanation is that

\footnotetext{
${ }^{18}$ We find it more meaningful to compare imports valued at the port of exit with exports valued at purchaser prices. The reason is that both have been delivered to their respective port of exit, so both values include domestic distribution costs but not international distribution costs.
} 
Table 5

Sector income shares of land, structures, and equipment (in purchaser prices)

\begin{tabular}{l|c|ccc}
\hline & Capital & Land & Structures & Equipment \\
\hline Agriculture (A) & 0.41 & 0.11 & 0.11 & 0.19 \\
Manufactured consumption (M) & 0.33 & 0.04 & 0.09 & 0.20 \\
Services (S) & 0.35 & 0.06 & 0.17 & 0.12 \\
Equipment investment (E) & 0.33 & 0.03 & 0.09 & 0.21 \\
Construction investment (C) & 0.21 & 0.03 & 0.05 & 0.13 \\
\hline Agriculture (A) & 0.41 & 0.11 & 0.11 & 0.19 \\
Manufacturing (M+E+C) & 0.31 & 0.03 & 0.09 & 0.19 \\
Services (S) & 0.35 & 0.06 & 0.17 & 0.12 \\
\hline Consumption (A+M+S) & 0.35 & 0.06 & 0.15 & 0.14 \\
Investment (E+C) & 0.28 & 0.03 & 0.07 & 0.18 \\
\hline Tradables (A+M+E) & 0.33 & 0.04 & 0.09 & 0.20 \\
Nontradables (S+C) & 0.34 & 0.06 & 0.16 & 0.12 \\
\hline Agriculture (A) & 0.41 & 0.11 & 0.11 & 0.19 \\
Nonagriculture (M+S+E+C) & 0.33 & 0.05 & 0.13 & 0.15 \\
\hline GDP (A+M+S+E+C) & 0.33 & 0.05 & 0.13 & 0.15 \\
\hline
\end{tabular}

distribution services are as capital intensive as the rest of the service sector, and thus less capital intensive than agriculture and manufactured consumption.

\subsection{Multi-sector models with intermediate inputs}

Our initial production function (1) assumed that the model does not have intermediate inputs. While this is fine in many cases, some applications require us to account explicitly for each sector's use of intermediate inputs from other sectors. In this subsection, we offer some factor income shares in this case. The production function of sector $j$ gross output is now given by:

$$
\frac{g_{j}}{p_{j}}=A_{j} k_{j}{ }^{\mu_{k j}} h_{j}^{\mu_{h j}} \prod_{i} z_{i j}{ }^{\mu_{i j}},
$$


where $z_{i j}$ are the intermediate inputs produced in sector $i$ and used in sector $j$ with $i, j \in$ $\{A, M, S, E, C\}$. Constant returns require that

$$
\mu_{k j}+\mu_{h j}+\sum_{i} \mu_{i j}=1
$$

The presence of intermediate inputs complicates measuring factor income shares at the sectoral level more than it may seem at first sight. The complication arises because constructing our five sectors requires us to split the deliveries of commodities to final uses into their consumption and investment parts. However, the consumption and investment parts of total output, value added, and produced intermediate inputs are not defined. The simple reason is that most commodities are neither consumption nor investment goods but both; for example, cars sold to firms are counted as investment whereas cars sold to consumers are counted as consumption. This implies that the IO tables do not offer a consistent categorization of the intermediate inputs into consumption and investment.

Not all is lost though because the splits into tradable versus nontradable, services versus nonservices, and agriculture versus nonagriculture each correspond to mutually exclusive sets of commodities. We can therefore categorize all intermediate inputs into these categories and provide factor shares with intermediate inputs for a subset of the sector splits considered above: agriculture and nonagriculture; agriculture, manufacturing, and services; tradables versus nontradables. Tables 6-8 report the corresponding factor income shares and Appendix A.2 reports the corresponding aggregate IO tables. Note that the income shares of capital and labor add up to the share of value added in gross output, which in general differs from the value of deliveries to final uses.

\section{Conclusion}

We have measured the U.S. income shares of capital and labor for the standard sectors used in multi-sector versions of the growth model. We have also split the income shares of capital into the shares of land, structures, and equipment. We have found that these factor income 
Table 6

Income shares of capital, labor, and intermediate inputs in the gross outputs of agriculture, manufacturing, and services (in producer prices)

\begin{tabular}{l|ccccc}
\hline & & & \multicolumn{3}{c}{ Intermediates from } \\
\cline { 4 - 6 } & Capital & Labor & $\begin{array}{c}\text { Agricul- } \\
\text { ture }\end{array}$ & $\begin{array}{c}\text { Manufac- } \\
\text { turing }\end{array}$ & Services \\
\hline Agriculture (A) & 0.20 & 0.15 & 0.27 & 0.18 & 0.20 \\
Manufacturing (M+E+C) & 0.12 & 0.22 & 0.03 & 0.39 & 0.24 \\
Services (S) & 0.21 & 0.44 & 0.00 & 0.08 & 0.27 \\
\hline
\end{tabular}

Table 7

Income shares of capital, labor, and intermediate inputs in the gross outputs of tradables and nontradables (in producer prices)

\begin{tabular}{c|cccc}
\hline & & & \multicolumn{2}{c}{ Intermediates from } \\
\cline { 4 - 5 } & Capital & Labor & Tradables & Nontradables \\
\hline Tradables $(\mathrm{A}+\mathrm{M}+\mathrm{E})$ & 0.13 & 0.19 & 0.44 & 0.24 \\
Nontradables $(\mathrm{S}+\mathrm{C})$ & 0.20 & 0.43 & 0.09 & 0.28 \\
\hline
\end{tabular}

Table 8

Income shares of capital, labor, and intermediate inputs in the gross outputs of agriculture and nonagriculture (in producer prices)

\begin{tabular}{l|cccc}
\hline & & & \multicolumn{2}{c}{ Intermediates from } \\
\cline { 4 - 5 } & Capital & Labor & Agriculture & Nonagriculture \\
\hline Agriculture (A) & 0.20 & 0.15 & 0.27 & 0.38 \\
Nonagriculture $(\mathrm{M}+\mathrm{S}+\mathrm{E}+\mathrm{C})$ & 0.18 & 0.37 & 0.01 & 0.44 \\
\hline
\end{tabular}


shares differ across sectors. For example, the capital share of agriculture is more than two and a half times that of construction and more than 50\% larger than that of the aggregate economy. Moreover, agriculture has by far the largest land share, which mostly explains why it has the largest capital share.

Our numbers can directly be used to calibrate multi-sector models. Moreover, if one wants to abstract from differences in sector capital shares, our numbers can be used to establish that this is not crucial for the results.

An interesting question is whether the U.S. income shares at the sectoral level are representative for other countries. Gollin (2002) and Bernanke and Gürkaynak (2001) found that the average aggregate capital share across countries equals the U.S. aggregate capital share. We leave it to future research to explore whether on average this is also the case at the sectoral level.

\section{References}

Bentolila, Samuel and Gilles Saint-Paul, "Explaining Movements in the Labor Share," Contributions to Macroeconomics, Berkeley Electronic Press, 2003, 3, 1103-1103.

Bernanke, Ben S. and Refet Gürkaynak, "Is Growth Exogenous? Taking Mankiw, Romer, and Weil Seriously," in Ben S. Bernanke and Kenneth Rogoff, eds., NBER Macroeconomics Annual 2001, Cambridge, MA: MIT Press, 2001.

Bureau of Economic Analysis, "Concepts and Methods of the U.S. Input-Output Accounts," 2006. http://bea.gov/bea/papers/IOmanual_092906.pdf.

Chari, Varadarajan V., Patrick J. Kehoe, and Ellen R. McGrattan, "The Poverty of Nations: a Quantitative Exploration," Staff Report 204, Federal Reserve Bank of Minneapolis, Research Department 1996. 
Davis, Morris A. and Jonathan Heathcote, “The Price and Quantity of Residential Land in the United States," Manuscript, Federal Reserve Board and Georgetown University, Washinton 2004.

Gollin, Douglas, “Getting Incomes Shares Right,” Journal of Political Economy, 2002, 110, $458-474$.

Hsieh, Chang-Tai and Peter J. Klenow, "Relative Prices and Relative Prosperity," American Economic Review, 2007, 97, 562-585.

Huffman, Gregory W. and Mark A. Wynne, "The Role of Intratemporal Adjustment Costs in a Multisector Economy," Journal of Monetary Economics, 1999, 43, 317-350.

Kongsamut, Piyabha, Sergio Rebelo, and Danyang Xie, "Beyond Balanced Growth," Review of Economic Studies, 2001, 68, 869-882.

Krueger, Alan B., "Measuring Labor's Share," American Economic Review (Papers and Proceedings), 1999, 89, 45-51.

Leamer, Edward E., "The Leontief Paradox, Reconsidered," Journal of Political Economy, 1980, 88, 495-503.

Leontief, Wassily, "Domestic Production and Foreign Trade: The American Capital Position Reexamined," Economia Internatiozionale, 1954, 7, 3-32. Reprinted in Richard. E. Caves and Harry G. Johnson, Readings in International Economics, Irwin, 1968.

Mundlak, Yair, "Economic Growth: Lessons from Two Centuries of American Agriculture," Journal of Economic Literature, 2005, 43, 989-1024.

Obstfeld, Maurice and Kenneth Rogoff, Foundation of International Macroeconomics, Cambridge, MA: MIT Press, 1996.

Stockman, Alan C. and Linda L. Tesar, "Tastes and Technology in a Two-Country Model of the Business Cycle: Explaining International Comovements," American Economic Review, 1995, 85, 168-185. 
ten Raa, Thijs, The Economics of Input-Output Analysis, Cambridge, UK: Cambridge University Press, 2005.

Young, Andrew T., “One of the Things we Know that Ain't So: Is U.S. Labor's Share Relatively Stable?," Manuscript, University of Mississippi 2006.

Zuleta, Hernando and Andrew T. Young, "Labor's Shares - Aggregate and Industry: Accounting for Both in a Model of Unbalanced Growth with Induced Innovation," Manuscript, University of Mississippi 2007. 


\section{Appendix}

\section{A.1 Aggregated IO-tables}

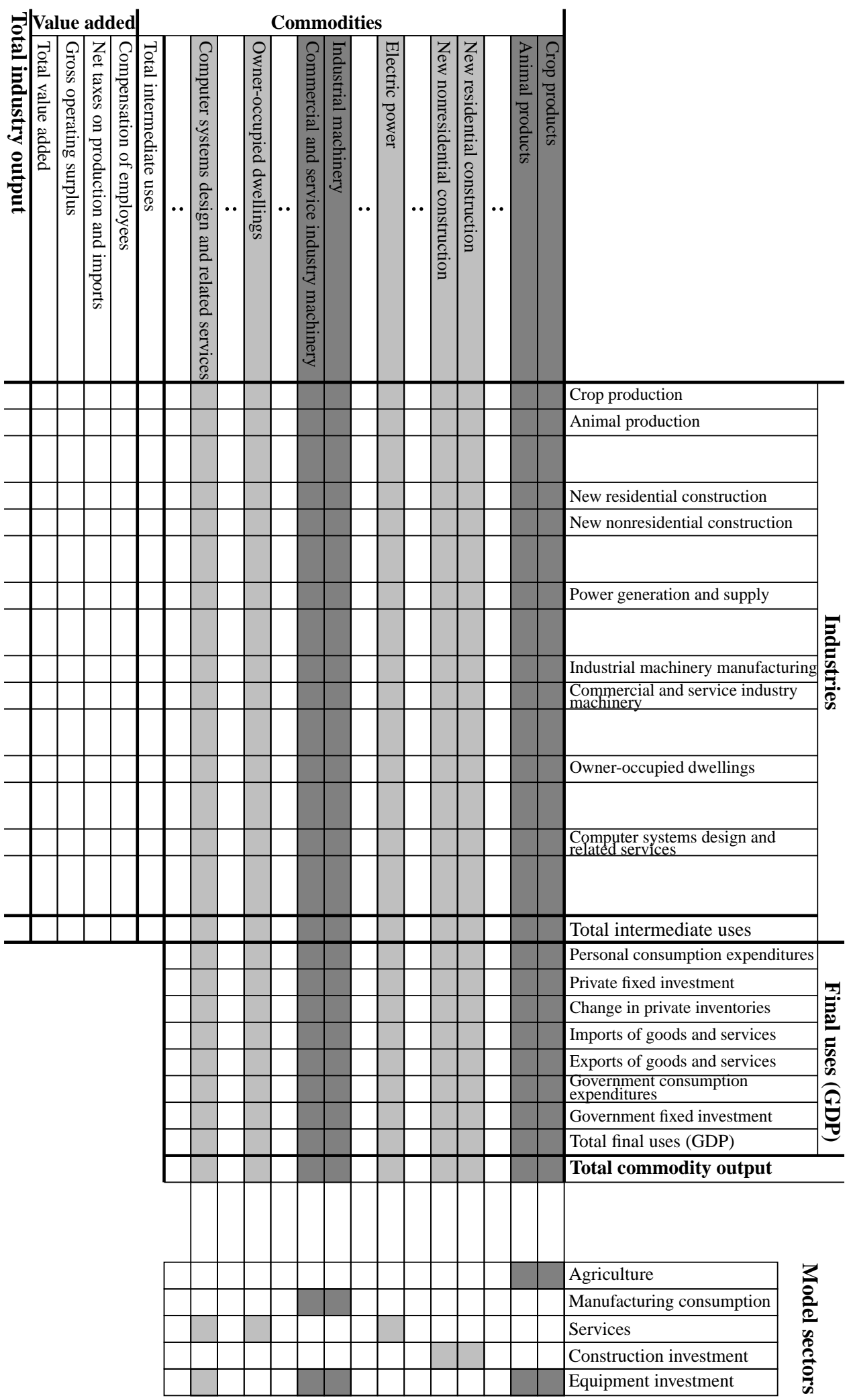


Use matrix for agriculture, manufacturing, construction and services

(in billions of U.S. \$)

\begin{tabular}{|c|c|c|c|c|c|c|c|c|c|}
\hline & A & $\mathrm{M}+\mathrm{E}$ & $\mathrm{C}$ & $\mathrm{S}$ & $\begin{array}{r}\text { Total } \\
\text { inter. } \\
\text { use }\end{array}$ & $\mathrm{C}$ & $\mathrm{X}$ & GDP & $\begin{array}{l}\text { Total } \\
\text { com. } \\
\text { output }\end{array}$ \\
\hline Agriculture (A) & 75 & 153 & 2 & 13 & 243 & 38 & 5 & 43 & 286 \\
\hline Manufacturing $(M+E)$ & 50 & 1555 & 228 & 645 & 2478 & 858 & 568 & 1426 & 3904 \\
\hline Construction (C) & 1 & 8 & 1 & 62 & 72 & 23 & 659 & 682 & 754 \\
\hline Services (S) & 55 & 920 & 199 & 2550 & 3724 & 5988 & 207 & 6195 & 9919 \\
\hline Total intermediate use & 181 & 2636 & 430 & 3270 & & & & & \\
\hline Net taxes & 6 & 57 & 6 & 578 & & & & & \\
\hline Labor & 43 & 734 & 295 & 4060 & & & & & \\
\hline Equipment & 24 & 335 & 11 & 771 & & & & & \\
\hline Structures & 10 & 146 & 3 & 874 & & & & & \\
\hline Land & 23 & 24 & 8 & 338 & & & & & \\
\hline Total value added & 106 & 1296 & 323 & 6621 & & & & 8346 & \\
\hline Total industry output & 287 & 3932 & 753 & $\overline{9891}$ & & & & & 14863 \\
\hline
\end{tabular}




\section{Discussion Papers published since 2005}

\section{5}

Gábor BÉKÉS - Balázs MURAKÖZY: Firm Behaviour and Public Infrastructure: The Case of Hungary. MT-DP. 2005/4

Gusztav NEMES: The Politics of Rural Development in Europe. MT-DP. 2005/5

Gusztav NEMES: Integrated Rural Development - the Concept and Its Operation. MT-DP. 2005/6

JUHÁSZ Anikó -SERES Antal -STAUDER Márta: A kereskedelmi koncentráció tendenciái MT-DP. 2005/7

Hajnalka TARJÁNI: Estimating some Labour Market Implications of Skill Biased Technology Change and imports in Hungary. MT-DP. 2005/8

L. HALPERN - M.KOREN.- Á. SZEIDL: Import and Productivity. MT-DP. 2005/9

Szabolcs LŐRINCZ: Persistence Effects in a Dynamic Discrete Choice Model Application to Low-End Computer Servers. MT-DP. 2005/10

Péter VIDA: A Detail-free Mediator and the 3 Player Case. MT-DP. 2005/11

László Á. KÓCZY: The Core Can Be Accessed with a Bounded Number of Blocks. MT-DP. 2005/12

Viktória KOCSIS: Network Asymmetries and Access Pricing in Cellular Telecommunications. MT-DP. 2005/13

István KÓNYA: Economic Development, Exchange Rates, and the Structure of Trade. MT-DP. 2005/14

Gábor G. SZABÓ - Krisztina BÁRDOS: Vertical Coordination by Contracts in Agribusiness: An Empirical Research in the Hungarian Dairy Sector MT-DP. 2005/15

Attila AMBRUS: Theories of Coalitional Rationality. MT-DP. 2005/16

Jin-Chuan DUAN - András FÜLÖP: Estimating the Structural Credit Risk Model When Equity Prices Are Contaminated by Trading Noises. MT-DP. 2005/17

Lawrence UREN - Gábor VIRÁG: Wage Inequality in a Burdett-Mortensen World. MT-DP. 2005/18

Berthold HERRENDORF - Ákos VALENTINYI: Which Sectors Make the Poor Countries so Unproductive? MT-DP. 2005/19

János GÁCS: The Macroeconomic Conditions of EU-inspired Employment Policies. MT-DP. 2005/20

CSATÓ Katalin: Egy fiziokrata: Paul-Pierre Le Mercier de la Rivière. MT-DP. $2005 / 21$

\section{6}

Krisztina MOLNÁR - Sergio SANTORO: Optimal Monetary Policy When Agents Are Learning. MT-DP. 2006/1

András SIMONOVITS: Social Security Reform in the US: Lessons from Hungary. MT-DP. 2006/2

Iván MAJOR - Why do (or do not) banks share customer information?. A comparison of mature private credit markets and markets in transition. MT-DP. 2006/3

Mária LACKÓ: Tax Rates with Corruption: Labour-market Effects. Empirical Cross-country Comparisons on OECD Countries. MT-DP. 2006/4

György MOLNÁR - Zsuzsa KAPITÁNY: Mobility, Uncertainty and Subjective Well-being in Hungary. MT-DP. 2006/5 
Rozália PÁL - Roman KOZHAN: Firms' investment under financing constraints. A euro area investigation. MT-DP. 2006/6

Anna IARA: Skill diffusion by temporary migration? Returns to Western

European working experience in the EU accession countries. MT-DP. 2006/7

György MOLNÁR - Zsuzsa KAPITÁNY: Uncertainty and the Demand for

Redistribution. MT-DP. 2006/8

Péter BENCZÚR - István KÓNYA: Nominal growth of a small open economy. MT-

DP. 2006/9

Gábor VIRÁG: Outside offers and bidding costs. MT-DP. 2006/10

Péter CSÓKA - P. Jean-Jacques HERINGS - László Á. KÓCZY: Coherent Measures of Risk from a General Equilibrium Perspective. MT-DP. 2006/11

Norbert MAIER: Common Agency with Moral Hazard and Asymmetrically

Informed Principals. MT-DP.2006/12

CSERES-GERGELY Zsombor - CSORBA Gergely: Múkincs vagy múködő tőke?

Gondolatok a kutatási célú adatok hozzáférhetőségéről. MT-DP.2006/13

Dr. SERES Antal: Koncentráció a hazai kereskedelemben. MT-DP.2006/14

Balázs ÉGERT: Central Bank Interventions, Communication and Interest Rate

Policy in Emerging European Economies. MT-DP.2006/15

Gábor BÉKÉS - Jörn KLEINERT - Farid TOUBAL: Spillovers from Multinationals to Heterogeneous Domestic Firms: Evidence from Hungary. MT-DP.2006/16

\section{7}

Mirco TONIN: Minimum Wage and Tax Evasion: Theory and Evidence. MTDP.2007/1

Mihály LAKI: Evolution on the market of foreign language teaching services in Hungary. MT-DP.2007/2

VINCZE Péter: Vállalatok tulajdonosi irányításának változatai. MT-DP.2007/3

Péter CSÓKA - P. Jean-Jacques HERINGS - László Á. KÓCZY: Stable Allocations of Risk. MT-DP. 2007/4

Judit TEMESVÁRY: Signal Extraction and Hyperinflations with a Responsive Monetary Policy. MT-DP. 2007/5

Péter KARÁDY - Ádám REIFF: Menu Costs and Inflation Assymmetries. Some Micro Data Evidence. MT-DP. 2007/6

Mária LACKÓ: Interrelationships of the Hidden Economy and Some Visible Segments of the Labour Market. MT-DP. 2007/7

HERMANN Zoltán: Iskolai kiadási egyenlőtlenségek, 1992-2005. MT-DP.2007/8

\section{8}

CSERES-GERGELY Zsombor - MOLNÁR György: Háztartási fogyasztói magatartás és jólét Magyarországon. Kísérlet egy modell adaptációjára. MTDP.2008/1

JUHÁSZ Anikó - KÜRTI Andrea - SERES Antal - STAUDER Márta: A kereskedelem koncentrációjának hatása a kisárutermelésre és a zöldséggyümölcs kisárutermelők alkalmazkodása. Helyzetelemzés. MT-DP.2008/2

Discussion Papers are available at the website of Institute of Economics Hungarian Academy of Sciences: http://econ.core.hu 